\title{
"Rolling regression technique and cross-sectional regression: A tool to analyze Capital Asset Pricing Model"
}

\begin{tabular}{|c|c|}
\hline AUTHORS & $\begin{array}{l}\text { Soumya Shetty (i) } \\
\text { Janet Jyothi Dsouza (i) } \\
\text { lqbal Thonse Hawaldar (D) } \\
\mathbb{R}\end{array}$ \\
\hline ARTICLE INFO & $\begin{array}{l}\text { Soumya Shetty, Janet Jyothi Dsouza and lqbal Thonse Hawaldar (2021). Rolling } \\
\text { regression technique and cross-sectional regression: A tool to analyze Capital } \\
\text { Asset Pricing Model. Investment Management and Financial Innovations, 18(4), } \\
241-251 \text {. doi:10.21511/imfi.18(4).2021.21 }\end{array}$ \\
\hline DOI & http://dx.doi.org/10.21511/imfi.18(4).2021.21 \\
\hline RELEASED ON & Thursday, 25 November 2021 \\
\hline RECEIVED ON & Wednesday, 01 September 2021 \\
\hline ACCEPTED ON & Thursday, 18 November 2021 \\
\hline LICENSE & $\begin{array}{l}(c) \text { EY } \\
\text { This work is licensed under a Creative Commons Attribution } 4.0 \text { International } \\
\text { License }\end{array}$ \\
\hline JOURNAL & "Investment Management and Financial Innovations" \\
\hline ISSN PRINT & $1810-4967$ \\
\hline ISSN ONLINE & $1812-9358$ \\
\hline PUBLISHER & LLC "Consulting Publishing Company "Business Perspectives" \\
\hline FOUNDER & LLC "Consulting Publishing Company "Business Perspectives" \\
\hline $0^{\circ}$ & $\begin{array}{l}\text { ニニニ } \\
\text { ニ= }\end{array}$ \\
\hline NUMBER OF REFERENCES & NUMBER OF FIGURES \\
\hline 50 & 5 \\
\hline
\end{tabular}

(c) The author(s) 2022. This publication is an open access article. 


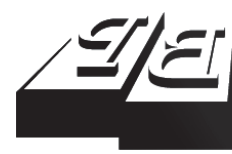

\section{BUSINESS PERSPECTIVES}

LLC "CPC "Business Perspectives" Hryhorii Skovoroda lane, 10, Sumy, 40022, Ukraine www.businessperspectives.org
Received on: $1^{\text {st }}$ of September, 2021 Accepted on: $18^{\text {th }}$ of November, 2021 Published on: $25^{\text {th }}$ of November, 2021

(c) Soumya Shetty, Janet Jyothi Dsouza, Iqbal Thonse Hawaldar, 2021

Soumya Shetty, MBA, Research Scholar, Ballari Institute of Technology and Management, India.

Janet Jyothi Dsouza, Ph.D., Associate Professor, Finance Faculty, Ballari Institute of Technology and Management, India.

Iqbal Thonse Hawaldar, Ph.D., Professor, Department of Accounting and Finance, College of Business Administration, Kingdom University, Bahrain. (Corresponding author)
This is an Open Access article, distributed under the terms of the Creative Commons Attribution 4.0 International license, which permits unrestricted re-use, distribution, and reproduction in any medium, provided the original work is properly cited.

Conflict of interest statement: Author(s) reported no conflict of interest

ROLLING REGRESSION TECHNIQUE AND CROSSSECTIONAL REGRESSION: A TOOL TO ANALYZE CAPITAL
ASSET PRICING MODEL

\begin{abstract}
The Capital Asset Pricing Model (henceforth, CAPM) is considered an extensively used technique to approximate asset pricing in the field of finance. The CAPM holds the power to explicate stock movements by means of its sole factor that is beta co-efficient. This study focuses on the application of rolling regression and cross-sectional regression techniques on Indian BSE 30 stocks. The study examines the risk-return analysis by using this modern technique. The applicability of these techniques is being viewed in changing business environments. These techniques help to find the effect of selected variables on average stock returns. A rolling regression study rolls the data for changing the windows for every 3 -month period for three years. The study modifies the model with and without intercept values. This has been applied to the monthly prices of 30 BSE stocks. The study period is from January 2009 to December 2018. The study revealed that beta is a good predictor for analyzing stock returns, but not the intercept values in the developed model. On the other hand, applying cross-section regression accepts the null hypothesis. $\alpha, \beta, \beta 2 \neq 0$. Therefore, a researcher is faced with the task of finding limitations of each methodology and bringing the best output in the model.
\end{abstract}

\section{Keywords}

JEL Classification

\section{INTRODUCTION}

CAPM plays an important role in the field of finance. This model has been more often used to know the cost of equity capital. The model strongly believes in a direct relationship between beta and stock return based on market returns (Kumar et al., 2018; Bolar et al., 2017). The theory states that beta is always proportional to gain an extra premium in a given market. CAPM has been around since 1964, and the person behind upholding the theory is William Sharpe. Gradually this theory has been developed by Lintner (1965) and Black et al. (1972). An extension of this model was made possible by a principle given by Markowitz (1952) in his modern portfolio theory. Later, the year criticism emerged in different backgrounds by researchers such as Banz (1981) who favored size effect on stock returns; the Fama-French three-factor model stated beta remained flat for the stock of higher returns (Fama \& French, 1992), Arbitrage theory, Multi-factor model (Fama \& French, 1996) and so on. Black (1993) raised an argument against Banz (1981) stating that the size effect was not able to agree with the viewpoints of the CAPM theory. Black (1993) found that the limitation of CAPM was wrongly misinterpreted. He found that data mining needs to be applied to prove the CAPM. Gradually, many more theories appeared with their strong viewpoints saying the beta alone cannot be the deciding factor for stock price movements, rather 
there are many more factors that need to be considered. Most of previous works experimented on economically advanced countries (Iqbal et al., 2007; Kumar et al., 2020). Some theories like the three-factor model (Fama \& French, 1993) considered value premium, size factors along with beta factors, multifactor model (Fama \& French, 1996), new anomalies on CAPM (Fama \& French, 2008). This study's purpose is to apply a rolling regression technique and cross-sectional regressions to check the soundness of the CAPM model in the framework of the Indian stock market for the present scenario. The study aims to analyze the risk-return analysis of the CAPM model for the study period 2009 to 2018. The study answers the question of does beta still hold the power to predict the variability of stock returns. The rolling regression application gives an understanding of mean-variance efficiency employing cross-sectional regression techniques. This technique considers two variables such as intercept and beta. By bringing modifications to these parameters, the effectiveness of the models has been examined. The reason for selecting CAPM is that it has not lost its power to explain stock returns, and this has been understood with the supportive statement of many researchers. This study examines CAPM from the latest period point of view in the changing business environment. It has been verified whether the market risk holds good for the present scenario. Nevertheless, from the previous study it is clear that rolling regression can produce most accurate results and a suitable technique to check this single factor model. With the sample size of 30 BSE SENSEX stocks and five portfolios, the study can provide appropriate conclusions to the issue concerned. If the results favor the beta power, one can definitely use it as one of the criteria to choose the security. Meanwhile, applying the present methodology interchangeably makes one prove the strength of the beta coefficient in predicting expected stock returns.

\section{LITERATURE REVIEW}

There have been many studies examining CAPM in Indian and international contexts. It has been observed that the scarce literature supported the relevance of CAPM in the markets, and some studies sharply criticized this theory. Iqbal (2011) reviewed 36 prominent research publications on the relevance of CAPM on the Indian and international stock market and concluded that there is no conclusive evidence to prove that CAPM is relevant to measuring risk and return. Iqbal (2015) empirically tested CAPM on Bahrain Bourse and concluded that the intercept test of the capital asset pricing model proves the theory, and the beta test goes against the standard theory. Hawaldar (2016) tested the cross-sectional variation in portfolio returns based on a sample of 30 companies listed on Bahrain Bourse and found that the results of the F-test indicate that the regression is not a good fit in the majority of the years of the study. Al-Afeef's (2017) study result proclaims that only $20 \%$ ability to make changes in stock returns is due to beta factors, and the remaining portions are because of other governing factors. Bajpai and Sharma (2015) show the support to CAPM in considering beta variables in the constrained model. The traditional model fails to fulfill the belief of CAPM theory. Hasan et al. (2011) reveal that intercept values and unique risks are not consistent as per the CAPM hypothesis, but the security market line (market risk) is in support of the CAPM. Choudhary and Choudhary (2010) disclose that beta has a linear relationship for its risk and return but not residual variance. Diwani and Asgharian (2010) uncover the intercept and slope coefficient are not in the line with significance. The residual variance also shows the non-linearity to stock returns but beta values are consistent with stock returns. Dhankar and Saini (2007) expose contradictory results as it brings consistency in the result of different sub-periods between different portfolio returns and systematic risk but not for the portfolios and price earning ratios. On the whole, this study can justify CAPM expectations. Gursoy and Rejepova (2007) show that the Mac Beth (1973) and Pettengill methodology results in different outcomes. The Pettengill methodology is consistent with the CAPM model, and the Macbeth methodology is not supportive of the CAPM model. Iqbal (2014) and Iqbal and Brooks (2007) conclude that the beta can explain changes in stock returns. Ansari (2000) has strongly upheld CAPM on the ground that parameter selection made by different authors is the reason for concluding the paper was unsupportive to the CAPM model. He found a deficiency in their asset pricing theories in terms of sample selection, methodology application, analysis mismatch, and 
market proxy selection. He also found that the sample selection bias fails to understand human behavior and psychology. This study understood that the expected return for the stock is possible because of covariance between stocks and the market index. Andor et al. (1999) demonstrate partial consistent results related to the CAPM model. This is because beta does not show a higher percentage in explaining stock returns and $r^{2}$ is only to the extent of 15\%-20\%. Fletcher (1997) announces a significant risk-return relationship under conditional approaches but not in the case of unconditional approaches. The whole study emphasizes power of beta in stock returns. Isakov (1999) (the residual risk (unique risk)) shows the negative results on average returns of the stocks. The study concluded that beta maintained its power on return on portfolios. Black (1993) emphasized that rational investors consider systematic risk in their investment decisions to estimate positive stock returns. He focused on data mining issues of authors to disprove the CAPM theory. Lau (1974) claims that in the Japanese stock market, CAPM holds under the time series regression model, as well as the cross-sectional regression model. Black et al. (1972) justified a linear relationship between risk and return in sample data. The study also found the prominence of beta in deciding asset pricing. Jensen (1968), in the study of beta stability, found out that mutual fund stocks are more stable than stock returns. Lintner (1965) examined the correlation between diversification in investment with different parameters such as security prices, degree of risk, and stock gains. The study interprets that common stocks are risky investments, and there is an indirect relationship between risk and different considered parameters. Sharpe (1964) revealed that the activeness in the economic activity expected returns of efficient combinations shows perfect correlation in the results. Markowitz (1952) revealed that an investor's judgemental behavior, as well as rational thinking and action, reflects favorable results in stock returns and variance.

Zhou et al. (2018) found no significant relationship between risk and return in both test methodologies. Shaikh et al. (2017) proved that for the chosen sample, CAPM does not show any relevant results. Bhatnagar and Indies (2013), in justifying only the three-factor model of 2006, show superior and achievable results as compared to CAPM that fails to meet the linearity in the return and value premium relationship for the United Kingdom Stocks. Hanif and Bhatti (2010) used sample data of 360 stocks and found that only 28 observed results were consistent with CAPM principles, while the rest were not. Therefore, the study does not accept the CAPM model as the right model to predict the required rate of return. Olakojo and Ajide (2010) experimented with ARCH tests that do not show consistency with the CAPM theory. The study found that residual risk also does not show any linearity between risk and return for different stocks. Amihud et al. (1992) have proved that beta is a good predictor to estimate expected stock returns. Theriou et al. (2010) show that the conditional approach and unconditional approach will not result in a positive risk and return relationship. Fama and French (2006) concluded a positive relationship between beta and value premium for the 1926 to 1963 study period and not for the study period of 1963 to 2004 . There is non-linearity between beta and stock returns for the study period 1926 to 2004. Bartholdy and Peare (2005) inform that the CAPM model and the Fama-French three-factor model are not good to use for the estimation of stock returns because CAPM finds only $3 \%$ variation in the return, whereas $5 \%$ in the case of the FF three-factor model. Fama and French (1996) examined anomalies in the CAPM. The study results support the theory of ICAPM and arbitrage pricing theories. Fama and French (1995) state that only the market index and size factor can predict stock returns positively but not market-to-book value. The market-to-book value shows negative results to stock returns. Berk (1995) theoretically justified that there is always an inverse relationship between the size and risk of any stock. This brings changes in average stock returns. Fama and French (1992) examined cross-sectional expected returns in considering three factors such as beta, size, and value premium. The study stated that beta remained flat for the stock of higher returns, and size and market-to-book ratios have direct relations to stock returns. Wong and Tan's (1991) study results are not consistent with the theory of CAPM. The study found negative and weak results for the CAPM by using variables like beta, beta square, unsystematic risk, total risks, and skewness. Fama and French (1993) in their study emphasize that five risk factors have a direct influence on the returns of stocks and bonds. 


\section{OBJECTIVES OF THE STUDY}

This study aims to find the applicability of the CAPM for the present scenario for the study period 2009 to 2018, using two analytical tools such as rolling regression analysis and cross-sectional regression.

\section{HYPOTHESES OF THE STUDY}

$H_{01}$ : There is no relationship between risk and return of stocks under the rolling regression technique.

$$
\begin{aligned}
& H_{01}=\alpha \neq 0, \\
& H_{01}=\beta \neq 0 .
\end{aligned}
$$

$H_{02}:$ There is no relationship between market risk and its variance to the average stock returns under cross section regression method.

$$
\begin{aligned}
& H_{02}=\beta \neq 0, \\
& H_{02}=\beta^{2} \neq 0 .
\end{aligned}
$$

\section{DATA AND METHODOLOGY}

\subsection{Data}

The data for the study is taken from the BSE website. The sample size is 30 BSE Sensex stocks. The BSE Sensex index is taken as a market benchmark to understand the relationship between risk and return. The risk-free rate of return is taken from the RBI bulletin. The study considered the implicit yield of 91-day treasury bills at the cut-off price. The study period commences from January 2009 to December 2018. This 10-year study considers monthly stock prices of each stock for the test period. The finding of beta is done using the firststage regression.

To ensure the stability of stock prices, stock returns are determined using log-returns each month for ten years for all the stocks. This is as follows:

$$
R_{i}=\ln \frac{P_{t}}{P_{t-1}}
$$

where $R_{i}$ - the return of each stock, $\ln -\log$ returns of the stocks, $P_{t}$ - current month price of the stocks, and $P_{t-1}$ - previous month price of the stocks.

\subsection{Methodology}

The capital asset pricing model is tested using two stages of regression. In the first stage regression, each stock returns $R_{i}$ are regressed for market returns $R_{M}$. With this, $\alpha$ and $\beta$ can arrive. The equation for the first stage regression is as follows:

$$
R_{i t}=\alpha_{i}+\beta_{i} R_{m t}+E_{i t},
$$

where $R_{i t}$ - return of each stock for the time period, $\alpha_{i}$-intercept value of the stock, $\beta_{i}$ - slope coefficient excess of market risk premium, $R_{M}-$ return of the market, and $E_{i t}$ - error term.

In the second stage, the regression market risk premium is calculated using the following equation:

$$
\left[E\left(R_{i t}-R_{f t}\right)\right]=\beta_{i m}\left[E\left(R_{m t}-R_{f t}\right)\right] .
$$

where $R_{f t}$ - risk free rate of return, $\left[E\left(R_{i t}-R_{f t}\right)\right]$ - expected average rate of return, $E\left(R_{m t}\right)$ - average expected market return, and $\beta_{i m}$ - market risk premium for each stock reach portfolios.

$\beta_{\text {im }}$ - can be calculated with the slope function or by applying the following formula:

$$
\beta_{i}=\frac{\operatorname{Cov}\left(r_{i} \cdot r_{m}\right)}{\sigma^{2}\left(r_{m}\right)} .
$$

The CAPM is tested using a rolling regression model. The rolling regression model gives an accurate picture of the validity of the CAPM model. To do this, data were divided into 29 sub-periods. Here three-year rolling regression was formed by moving windows every three months. This is done for the entire ten years of study periods. There are 29 sub-periods. The data are overlapping from current to previous sub-periods. Each sub-period includes 30 stocks for three years. The Capital Asset Pricing Model is applied to the portfolio. A total of 30 stocks are taken for the study, six portfolios can be formed. Each portfolio includes five stocks. This avoids the diversifiable risk factor. The portfolios are grouped based on the beta values of the stocks. A stock that has higher beta values is 
categorized as the first portfolio against least portfolios that have smaller beta values.

The sample has been tested using a two-stage regression model. This is done by modifying the intercept values. In the first case of application of the cross-sectional regression model, intercept values are considered, and to find the significance of the CAPM, the intercept value has to be zero. In the second case of the application, the intercept values will not be considered. The soundness of CAPM is verified using the regression slope co-efficient $(\beta)$, $F$-statistics, and explanation power of market index on stock returns $\left(r^{2}\right)$. This helps to know whether the application of these two methods makes any significant difference in the results or not.

\section{RESULTS AND DISCUSSION}

To examine the relevance of the CAPM model, two-stage regressions were applied for each sub-period for each of the portfolios. In the first case, intercept values were considered. The results of each portfolio for different sub-periods are as follows.

\subsection{Rolling regression results for different sub-periods with an intercept

$$
\left[E\left(R_{p}-R_{f}\right)\right]=\alpha_{p}+\beta_{p}\left[E\left(R_{m}-R_{f}\right)\right]
$$

Table 1 presents the results of rolling regression when the regression model has an intercept. The intercept values of all the sub-periods stand the negative figure, which indicates that intercept values are significant, and this does not show any constant return. This is not aligning with the CAPM theory. To accept the CAPM model, the intercept value has to be zero, which has to be statistically insignificant. This shows the occurrence of the abnormal return due to some external unknown fac-

Table 1. The results of rolling regressions for different sub-periods in consideration of an intercept

\begin{tabular}{|c|c|c|c|c|c|c|c|c|c|}
\hline No & Sub-period & Beta & $p$-values & intercept & $p$-values & Adj. $r^{2}$ & $f$ value & $p$-values & $t$-values \\
\hline 1 & $\operatorname{Jan} 09$ to Dec 11 & 1.081 & 0.001 & -0.007 & 0.391 & 0.571 & 71.891 & 0.001 & 7.757 \\
\hline 2 & April 09 to March 12 & 1.103 & 0.001 & -0.006 & 0.392 & 0.573 & 72.571 & 0.001 & 7.841 \\
\hline 3 & July 09 to June 12 & 1.045 & 0.000 & -0.007 & 0.393 & 0.470 & 45.103 & 0.000 & 6.180 \\
\hline 4 & Oct 09 to Sep 12 & 1.021 & 0.002 & -0.009 & 0.360 & 0.442 & 39.823 & 0.002 & 5.798 \\
\hline 5 & Jan 10 to Dec 12 & 1.042 & 0.002 & -0.010 & 0.341 & 0.440 & 42.085 & 0.002 & 5.872 \\
\hline 6 & April 10 to March 13 & 1.071 & 0.002 & -0.010 & 0.376 & 0.442 & 42.435 & 0.002 & 5.895 \\
\hline 7 & July 10 to June 13 & 1.085 & 0.002 & -0.011 & 0.341 & 0.444 & 45.420 & 0.002 & 6.021 \\
\hline 8 & Oct 10 to Sep 13 & 1.158 & 0.002 & -0.012 & 0.370 & 0.460 & 41.264 & 0.002 & 5.968 \\
\hline 9 & Jan 11 to Dec 13 & 1.170 & 0.000 & -0.009 & 1.052 & 0.511 & 47.902 & 0.000 & 6.032 \\
\hline 10 & April 11 to March 14 & 1.207 & 0.002 & -0.008 & 0.540 & 0.484 & 43.931 & 0.002 & 6.223 \\
\hline 11 & July 11 to June 14 & 1.240 & 0.001 & -0.009 & 0.503 & 0.506 & 47.299 & 0.001 & 6.495 \\
\hline 12 & Oct 11 to Sep 14 & 1.231 & 0.001 & -0.009 & 0.454 & 0.505 & 61.247 & 0.001 & 6.994 \\
\hline 13 & Jan 12 to Dec 14 & 1.293 & 0.002 & -0.013 & 0.397 & 0.357 & 28.674 & 0.002 & 4.822 \\
\hline 14 & April 12 to March 15 & 1.328 & 0.001 & -0.016 & 0.301 & 0.360 & 25.647 & 0.001 & 4.746 \\
\hline 15 & July 12 to June 15 & 1.390 & 0.001 & -0.018 & 0.197 & 0.339 & 21.979 & 0.001 & 4.470 \\
\hline 16 & Oct 12 to Sep 15 & 1.358 & 0.001 & -0.018 & 0.159 & 0.339 & 21.611 & 0.001 & 4.483 \\
\hline 17 & $\operatorname{Jan} 13$ to Dec 15 & 1.346 & 0.001 & -0.017 & 0.168 & 0.327 & 20.579 & 0.001 & 4.341 \\
\hline 18 & April 13 to March 16 & 1.307 & 0.000 & -0.016 & 0.183 & 0.380 & 25.164 & 0.000 & 4.849 \\
\hline 19 & July 13 to June 16 & 1.302 & 0.000 & -0.016 & 0.191 & 0.383 & 25.100 & 0.000 & 4.863 \\
\hline 20 & Oct 13 to Sep 16 & 1.317 & 0.000 & -0.014 & 0.203 & 0.431 & 32.115 & 0.000 & 5.438 \\
\hline 21 & Jan 14 to Dec 16 & 1.289 & 0.000 & -0.014 & 0.213 & 0.414 & 30.216 & 0.000 & 5.255 \\
\hline 22 & April 14 to March 17 & 1.283 & 0.000 & -0.013 & 0.231 & 0.421 & 30.744 & 0.000 & 5.315 \\
\hline 23 & July 14 to June 17 & 1.229 & 0.001 & -0.015 & 0.185 & 0.391 & 28.811 & 0.001 & 4.991 \\
\hline 24 & Oct 14 to sep 17 & 1.231 & 0.001 & -0.014 & 0.256 & 0.399 & 27.156 & 0.001 & 5.034 \\
\hline 25 & $\operatorname{Jan} 15$ to Dec 17 & 1.201 & 0.000 & -0.012 & 0.250 & 0.442 & 31.322 & 0.000 & 5.469 \\
\hline 26 & April 15 to March 18 & 1.083 & 0.000 & -0.010 & 0.253 & 0.449 & 35.044 & 0.000 & 5.662 \\
\hline 27 & July 15 to June 18 & 1.092 & 0.000 & -0.011 & 0.184 & 0.435 & 31.904 & 0.000 & 5.448 \\
\hline 28 & Oct 15 to Sep 18 & 1.144 & 0.000 & -0.012 & 0.155 & 0.458 & 35.261 & 0.000 & 5.724 \\
\hline 29 & Jan 16 to Dec 18 & 1.1153 & 0.0001 & -0.0137 & 0.133 & 0.474 & 37.559 & 0.000 & 5.912 \\
\hline
\end{tabular}


tors and this is not within the limit of the sample market index. But the market risk premium shows positive results. This shows the support for the CAPM model. The correlation between market returns and stock returns is quite strong in most of the sub-periods. The maximum $\left(r^{2}\right)(57.29 \%)$ arrives in the sub-period 2 (April 09 to March 12) and minimum $\left(r^{2}\right)(32.69 \%)$ is in the sub-period 17 (Jan 13 to Dec 15). The value of F-statistics shows significant results for all the sub-periods.

\subsection{Rolling regression for different sub-periods without an intercept formula}

$$
\left[E\left(R_{p}-R_{f}\right)\right]=\beta_{p}\left[E\left(R_{m}-R_{f}\right)\right]
$$

Table 2 gives the result of rolling regression without an intercept. If we compare rolling regression with an intercept, this table shows the comparatively lesser performance, but this favors the
CAPM model. The adjusted $\left(r^{2}\right)$ is satisfactory. The maximum $\left(r^{2}\right)(54.73 \%)$ is found in the sub-period 2 (April 09 to March 12) and the minimum $\left(r^{2}\right)(29.46 \%)$ is in the sub-period 15 (July 12 to June 15). F-statistics shows the statistically significant result for all the sub-periods except for the sub-period 15 (July 12 to June 15). The market risk premiums show statistically insignificant results for all the sub-periods and are positive outcomes. The study found statistically insignificant differences in the expected returns. The risk component is proportional to stock returns, and risk is within the purview of the market risk coefficient. This study accepts the null hypothesis that beta is zero or there is a positive direct relationship between stock returns and the risk of individual stocks. This study accepts the theory of the CAPM model. The overall study with the techniques of rolling regression says that beta has a positive impact in both cases but not the intercept of the regression model.

Table 2. Rolling regression for different sub-periods without an intercept

\begin{tabular}{|c|c|c|c|c|c|c|c|}
\hline No & Sub-periods & Market risk premium & $p$-values & Adj. $r^{2}$ & $f$-values & $p$-values & $t$-values \\
\hline 1 & Jan 09 to Dec 11 & 1.0683 & 0.0008 & 0.5462 & 72.13 & 0.0008 & 7.7610 \\
\hline 2 & April 09 to March 12 & 1.0915 & 0.0008 & 0.5473 & 72.74 & 0.0008 & 7.8202 \\
\hline 3 & July 09 to June 12 & 1.0456 & 0.0004 & 0.4494 & 44.88 & 0.0004 & 6.1669 \\
\hline 4 & Oct 09 to Sep 12 & 1.0303 & 0.0013 & 0.4266 & 40.28 & 0.0013 & 5.8394 \\
\hline 5 & Jan 10 to Dec 12 & 1.0538 & 0.0013 & 0.4254 & 42.80 & 0.0013 & 5.9237 \\
\hline 6 & April 10 to March 13 & 1.0871 & 0.0013 & 0.4295 & 43.69 & 0.0013 & 5.9856 \\
\hline 7 & July 10 to June 13 & 1.1014 & 0.0012 & 0.4311 & 46.65 & 0.0012 & 6.1017 \\
\hline 8 & Oct 10 to Sep 13 & 1.1942 & 0.0015 & 0.4563 & 43.81 & 0.0015 & 6.1699 \\
\hline 9 & Jan 11 to Dec.13 & 1.1908 & 0.0002 & 0.5010 & 50.10 & 0.0002 & 6.7086 \\
\hline 10 & April 11 to March 14 & 1.2184 & 0.0013 & 0.4697 & 44.96 & 0.0013 & 6.3006 \\
\hline 11 & July 11 to June 14 & 1.2357 & 0.0006 & 0.4840 & 47.26 & 0.0006 & 6.4860 \\
\hline 12 & Oct 11 to Sep 14 & 1.2039 & 0.0009 & 0.4797 & 60.60 & 0.0009 & 6.9393 \\
\hline 13 & $\operatorname{Jan} 12$ to Dec 14 & 1.2234 & 0.0025 & 0.3252 & 25.56 & 0.0027 & 4.6863 \\
\hline 14 & April 12 to March 15 & 1.2624 & 0.0009 & 0.3207 & 22.22 & 0.0011 & 4.4629 \\
\hline 15 & July 12 to June 15 & 1.3105 & 0.0011 & 0.2946 & 18.87 & 0.0428 & 3.8007 \\
\hline 16 & Oct 12 to Sep 15 & 1.3277 & 0.0005 & 0.3041 & 19.45 & 0.0010 & 4.2480 \\
\hline 17 & $\operatorname{Jan} 13$ to Dec 15 & 1.3291 & 0.0007 & 0.2982 & 19.04 & 0.0011 & 4.1939 \\
\hline 18 & April 13 to March 16 & 1.2911 & 0.0003 & 0.3508 & 23.92 & 0.0003 & 4.7240 \\
\hline 19 & July 13 to June 16 & 1.2788 & 0.0003 & 0.3493 & 23.49 & 0.0003 & 4.6981 \\
\hline 20 & Oct 13 to Sep 16 & 1.2863 & 0.0001 & 0.3944 & 30.30 & 0.0002 & 5.2544 \\
\hline 21 & Jan 14 to Dec 16 & 1.2872 & 0.0002 & 0.3879 & 29.55 & 0.0003 & 5.1816 \\
\hline 22 & April 14 to March 17 & 1.2670 & 0.0003 & 0.3903 & 29.63 & 0.0006 & 5.1970 \\
\hline 23 & July 14 to June 17 & 1.2338 & 0.0008 & 0.3668 & 26.58 & 0.0014 & 4.9205 \\
\hline 24 & Oct 14 to Sep 17 & 1.2432 & 0.0001 & 0.3709 & 26.22 & 0.0009 & 4.9363 \\
\hline 25 & Jan 15 to Dec 17 & 1.1978 & 0.0002 & 0.3607 & 29.88 & 0.0001 & 5.3272 \\
\hline 26 & April 15 to March 18 & 1.0898 & 0.0002 & 0.4198 & 33.99 & 0.0002 & 5.5577 \\
\hline 27 & July 15 to June 18 & 1.0816 & 0.0002 & 0.4035 & 30.59 & 0.0002 & 5.3206 \\
\hline 28 & Oct 15 to Sep 18 & 1.1143 & 0.0002 & 0.4169 & 32.28 & 0.0001 & 5.4713 \\
\hline 29 & Jan 16 to Dec 18 & 1.0853 & 0.0002 & 0.4262 & 33.69 & 0.0001 & 5.5856 \\
\hline
\end{tabular}




\section{CROSS-SECTIONAL REGRESSION}

The cross-sectional regression is calculated using the following regression model: Equation (3) is applied to estimate the risk coefficient of various variables, which produces the risk-return relationship. To prove the CAPM theory $\beta_{i}^{2}$, the coefficient should not be different from zero. This gives the output of a positive relationship between risk and return. This has been discussed below:

$$
\begin{aligned}
& \overline{R l}=\alpha_{0}+\alpha_{1} \beta_{i}+\alpha_{2} \beta_{i}^{2}+ \\
& +\alpha_{3} u r_{i}+\alpha_{4} s k w_{i}+U_{i},
\end{aligned}
$$

where $\bar{R}$ - average return of the whole sample, $\alpha_{0}$ - the intercept value of the whole sample, $\beta_{i}$ - beta coefficient obtained by regressing value of $R_{i}$ with $R_{m}, \beta_{i}^{2}$ - the square of beta, $u r_{i}$ - unsystematic risk $=\sigma_{i}^{2}-\beta_{i}^{2} \cdot \sigma_{m}^{2}, s k w_{i}-$ the average skewness of entire sample calculated through descriptive statistics, and $U_{i}$ - the regression residuals.

The results of ordinary least square regression are arrived at after verifying the residual standard errors across its data sets. If there is not much variance in the standard error of various variables, the results give accurate answers, through this, the right conclusions can be drawn. To check this, two normally distributed diagnostic tests have been applied. These are the heteroscedasticity test and the Jarque-Bera normality test. The results showed that there is no heteroscedasticity in the data sets, and the results of the Jarque-Bera test show the residuals are normally distributed.

\subsection{Heteroscedasticity tests}

To ensure the accurate results of cross-sectional regression, different risk coefficients must be free from standard errors among the independent factors. To do this, two diagnostic tests have been applied such as heteroscedasticity tests and JarqueBera normality tests.

\section{Hypothesis testing}

Null hypothesis: There is no heteroscadesity.

Table 3. Heteroskedasticity tests using the

\begin{tabular}{|c|c|c|c|}
\hline Statistics & Coefficient & Probability & p-values \\
\hline F-statistic & 2.447407 & Prob. $F(4,25)$ & 0.0726 \\
\hline Obs* $R$-squared & 8.441852 & $\begin{array}{c}\text { Prob. } \\
\text { Chi-Square(4) }\end{array}$ & 0.0767 \\
\hline $\begin{array}{l}\text { Scaled explained } \\
\text { SS }\end{array}$ & 5.364881 & $\begin{array}{c}\text { Prob. } \\
\text { Chi-Square(4) }\end{array}$ & 0.2519 \\
\hline
\end{tabular}
Breush-Pagan-Godfrey method

Table 3 shows the results of heteroscadasticity using the Breusch-Pagan-Godfrey method. The results show that at a $5 \%$ significance level, ChiSquare tests support the null hypothesis.

\subsection{Jarque-Bera normality tests}

Jarque-Bera tests were applied to check whether residual variances are normally distributed or not.

\section{Hypothesis testing}

Null hypothesis: Residuals are normally distributed.

Alternative hypothesis: Residuals are not normally distributed.

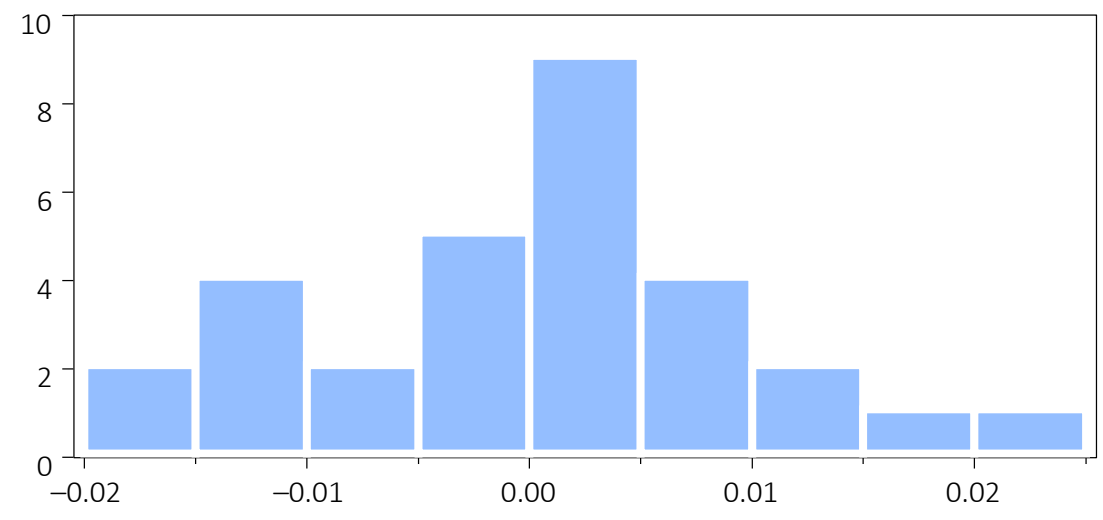

Figure 1. Jarque-Bera normality test
Series: Residuals

Sample 130

Observations 30

Mean $\quad 1.73 e-18$

Median $\quad 0.000723$

Maximum $\quad 0.023563$

Minimum $\quad-0.018735$

Std. Dev. $\quad 0.009957$

Skewness $\quad 0.194663$

Kurtosis $\quad 2.830269$

Jarque-Bera $\quad 0.225480$

Probability $\quad 0.893383$ 
Table 4. Summary statistics of the first stage regression

\begin{tabular}{|c|c|c|c|c|c|}
\hline Statistics & $\bar{R}$ & $A v g \beta$ & $A v g \beta^{2}$ & $A v g u r$ & Avg skw \\
\hline Average values & 0.006 & 1.12 & 1.50 & 0.017 & -3.23 \\
\hline Standard deviation & 0.01 & 0.48 & 1.21 & 0.01 & 3.30 \\
\hline Minimum & -0.01 & 0.31 & 0.09 & 0.00 & -9.12 \\
\hline Max & 0.03 & 2.22 & 4.96 & 0.05 & 1.17 \\
\hline Median & 0.006 & 1.10 & 1.21 & 0.01 & -2.99 \\
\hline
\end{tabular}

Table 5. Results of OLS estimates

\begin{tabular}{|c|c|c|c|c|c|}
\hline Statistics & $\alpha_{0}$ & $\beta_{i}$ & $\beta_{i}^{2}$ & $u r_{i}$ & $s k w_{i}$ \\
\hline Coefficients & -0.00 & 0.02 & -0.01 & 0.33 & 0.00 \\
\hline$T$-stat & -0.32 & 1.21 & -1.33 & 1.02 & 1.78 \\
\hline P-value & 0.74 & 0.23 & 0.19 & 0.31 & 0.08 \\
\hline Ajda square & 0.03 & & & & \\
\hline$F$-value & 1.28 & 0.30 & & & \\
\hline
\end{tabular}

Figure 1 favors the null hypothesis stating residuals are normally distributed at a 5\% significance level. This assures the authenticity of sample data for further research.

\subsection{Results and analysis based on the cross-sectional regression method}

The first stage regression model is applied to know the beta, alpha and other important variables of BSE 30 stocks. The average values of different variables and descriptive statistics of stocks are shown in Table 4.

Table 4, the first stage regression, gives satisfactory results as average return and beta values show the positivity. As skewness stands in the negative figure, which is -3.2342 , this gives the implication that the data sets of average returns are asymmetric. It has been found that data are not normally distributed. The result reveals positive unsystematic risk.

\subsection{OLS estimate results}

Table 5 shows cross-sectional regression results. The different coefficients are considered to check the relationship between average return and risks. This includes beta, beta square, unsystematic risk and skewness. Thus, the CAPM theory analyzes if there is any positive impact on these different coefficients. But looking at the table, the results reveal that all coefficients are insignificant and do not favor the CAPM model. The adjusted square implies that all these coefficients are not impacted much by the average return of the stocks.

\section{CONCLUSION}

The empirical study of the risk-return relationship using cross-sectional regression by taking different risk ratios, as well as rolling regression techniques, shows contradictory results. Rolling regression supports the CAPM model taking into consideration beta factors but not intercept factors. The study shows significant results to intercept values, but beta coefficients support the CAPM theory under the rolling regression method. But in the case of the cross-sectional method, all the tested coefficients show negative values in order to justify the CAPM model. On the whole, this study concludes that under rolling regression techniques, the CAPM perform as expected, but not in the case of cross-sectional regression for the chosen test period. There is no doubt that the beta still holds its power to estimate stock prices. This study also assures that different methodologies can yield different results. This indicates that the choice of an appropriate methodology makes the study supportive or not. Thus, this gives the scope for the future researcher to test the most suitable methodology to conclude the validity of the CAPM. 


\section{AUTHOR CONTRIBUTIONS}

Conceptualization: Soumya Shetty, Janet Jyothi Dsouza.

Data curation: Soumya Shetty.

Formal analysis: Soumya Shetty, Janet Jyothi Dsouza.

Funding acquisition: Iqbal Thonse Hawaldar.

Investigation: Janet Jyothi Dsouza.

Methodology: Janet Jyothi Dsouza.

Project administration: Iqbal Thonse Hawaldar.

Validation: Iqbal Thonse Hawaldar.

Writing - original draft: Soumya Shetty, Janet Jyothi Dsouza.

Writing - review \& editing: Iqbal Thonse Hawaldar.

\section{REFERENCES}

1. Al-Afeef, M. A. M. (2017). Capital Asset Pricing Model, Theory and Practice: Evidence from USA (2009-2016). International Journal of Business and Management, 12(8), 182. https://doi.org/10.5539/ ijbm.v12n8p182

2. Amihud, Y., Christensen, B. J., \& Mendelson, H. (1992). Further Evidence on the Risk-Return Relationship. In Research paper series.

3. Andor, G., Ormos, M., \& Szabó, B. (1999). Empirical tests of capital asset pricing model (CAPM) in the Hungarian capital market. Periodica Polytechnica Social and Management Sciences, 7(1), 47-64.

4. Ansari, V. A. (2000). Capital asset pricing model: Should we stop using it? Vikalpa, 25(1), 55-64. https://doi. org/10.1177/0256090920000114

5. Bajpai, S., \& Sharma, A. K. (2015). An Empirical Testing of Capital Asset Pricing Model in India. Procedia - Social and Behavioral Sciences, 189, 259-265. https://doi. org/10.1016/j.sbspro.2015.03.221

6. Banz, R. W. (1981). The relationship between return and market value of common stocks. Journal of Financial Economics, 9(1), 3-18. https:// doi.org/10.1016/0304405X(81)90018-0

7. Bartholdy, J., \& Peare, P. (2005). Estimation of expected return: CAPM vs . Fama and French. International Review of Financial
Analysis, 14, 407-427. https://doi. org/10.1016/j.irfa.2004.10.009

8. Barua, S. K. (1981). The ShortRun Price Behaviour of Securities: Some Evidence on Efficiency of Indian Capital Market. Vikalpa: The Journal for Decision Makers, 6(2), 93-100. https://doi. org/10.1177/0256090919810204

9. Basu, S. (2013). Investment Performance of Common Stocks in Relation to Their PriceEarnings Ratios. The Journal of Finance, 32(3), 663-682. https:// doi.org/10.2307/2326304

10. Berk, J. B. (1995). A Critique of Size-Related Anomolies. The Review of Financial Studies, 8(2), 275-286. https://doi.org/10.1093/ $\mathrm{rfs} / 8.2 .275$

11. Bhandari, L. C. (1988). Debt/ Equity Ratio and Expected Common Stock Returns: Empirical Evidence. The Journal of Finance, 43(2), 507-528. https:// doi.org/10.1111/j.1540-6261.1988. tb03952.x

12. Bhatnagar, C. S., \& Indies, T. W. (2013). The capital asset pricing model versus the three-factor model: A United Kingdom Perspective. International Journal of Business and Social Research, 2(1), 51-65. https://doi. org/10.18533/ijbsr.v2i1.204

13. Black, F. (1993). Beta and Return. The Journal of Portfolio Management, 20(1), 8-18. https:// doi.org/10.3905/jpm.1993.409462

14. Black, F., Jensen, M. C., \& Scholes, M. (1972). The Capital
Asset Pricing Model : Some Empirical Tests. Studies in the Theory of Capital Markets, 1-54. Retrieved from http://ssrn.com/ abstract $=908569$

15. Choudhary, K., \& Choudhary, S. (2010). Testing Capital Asset Pricing Model: Empirical Evidences from Indian Equity Market. Eurasian Journal of Business and Economics, 3(6), 127138. Retrieved from https://www. ejbe.org/index.php/EJBE/article/ view/44

16. Cohen, K. J., Hawawini, G. A., Maier, S. F., Schwartz, R. A., \& Whitcomb, D. K. (1980). Implications of Microstructure Theory for Empirical Research on Stock Price Behavior. The Journal of Finance, 35(2), 249. https://doi. org/10.2307/2327381

17. Dhankar, R. S., \& Saini, R. K. (2007). Portfolio Performance in Relation to Price Earning Ratio: A Test of Efficiency under different Economic Conditions. Icfai Journal of Applied Finance, 13(1), 223-232. https://doi. org/10.1007/978-81-322-39505_14

18. Diwani, M., \& Asgharian, $\mathrm{H}$. (2010). Testing the CAPM in the Indian A study that investigates the validity of the CAPM in Bombay Stock Exchange Sensex 30. Exchange Organizational Behavior Teaching Journal.

19. Fama, E. F., \& French, K. R. (1992). The Cross-Section of Expected Stock Returns. Source: The Journal 
of Finance, 47(2), 427-465. https:// doi.org/10.2307/2329112

20. Fama, E. F., \& French, K. R. (1995) Size and Book to Market Factors in Earnings and Returns. The Journal of Finance, L(1), 131-155. https:// doi.org/10.1111/j.1540-6261.1995. tb05169.x

21. Fama, E. F., \& French, K. R. (1996) Multifactor explanations of asset pricing anomalies. Journal of Finance, 51(1), 55-84. https://doi. org/10.1111/j.1540-6261.1996. tb05202.x

22. Fama, E. F., \& French, K. R. (2006). The value premium and the CAPM. Journal of Finance, 61(5), 2163-2185. https://doi.org/10.1111/ j.1540-6261.2006.01054.x

23. Fama, E. F., \& French, K. R. (2008) Dissecting anomalies. Journal of Finance, 63(4), 1653-1678. https://doi.org/10.1111/j.1540$6261.2008 .01371 \mathrm{x}$

24. Fama, E. F., \& MacBeth, J. D. (1973). Risk, Return, and Equilibrium: Empirical Tests. The Journal of Political Economy, 81(3), 607-636.

25. Fama, E. F., \& French, K. R. (1993). Common risk factors in the returns stocks and bonds. Journal of Financial Economics, 33, 3-56. https://doi.org/10.1016/0304405X(93)90023-5

26. Fletcher, J. (1997). An examination of the cross-sectional relationship of beta and return: UK evidence. Journal of Economics and Business, 49(3), 211-221. https://doi.org/10.1016/s01486195(97)00006-4

27. Gursoy, C. T., \& Rejepova, G. (2007). Test of Capital Asset Pricing Model in Turkey. Dogus Universitesi Dergisi, 8(1), 4758. https://doi.org/10.31671/ DOGUS.2019.241

28. Hanif, M., \& Bhatti, U. (2010). Validity of Capital Assets Pricing Model: Evidence from KSEPakistan. European Journal of Economics, Finance and Administrative Sciences, (20). Retrieved from https://ssrn.com/ abstract $/=1544287$

29. Hasan, M. Z., Kamil, A. A. Mustafa, A., \& Baten, M. A. (2011).
A Validity Test Of Capital Asset Pricing Model for Dhaka Stock Exchange. Journal of Applied Sciences, 11(20), 3490-3496. https:// doi.org/10.3923/jas.2011.3490.3496

30. Hawaldar, I. T. (2016). The Cross-Sectional Variations in Portfolio Returns Evidence from Bahrain Bourse. British Journal of Economics, Finance and Management Sciences, 12(2), 1-11.

31. Iqbal, J., \& Brooks, R. (2007). A Test of CAPM on the Karachi Stock Exchange. International Journal of Business, 12(4), 429-444. Retrieved from https://www.researchgate.net/ publication/228267073

32. Iqbal, T. H. (2011). Relevance of Capital Asset Pricing Model - A Review. Journal on Banking Financial Services and Insurance Research, 1(2), 85-97.

33. Iqbal, T. H. (2014). Seasonal analysis of abnormal returns after quarterly earnings announcements. International Journal of Accounting and Financial Reporting, 4(2), 501-519.

34. Iqbal, T. H. (2015). Empirical Testing of Capital Asset Pricing Model on Bahrain Bourse. Asian Journal of Finance \& Accounting, 7(2), 107-119. https://doi. org/10.5296/ajfa.v7i2.8356

35. Iqbal, T. H., Mallikarjunappa, $\mathrm{T}$, \& Nayak, P. (2007). Stock Price Adjustments to Quarterly Earnings Announcement: A Test of Semistrong Form of Efficiency. Gyan Management, 1(2), 25-42.

36. Isakov, D. (1999). Is beta still alive? Conclusive evidence from the Swiss stock market. The European Journal of Finance, 5(3), 202-212. https://doi. org/10.1080/135184799337046

37. Jensen, M. C. (1968). The Performance of Mutual Funds in the Period 1945-1964. The Journal of Finance, 23(2), 389-416. https:// doi.org/10.1111/j.1540-6261.1968 tb00815.x

38. Kumar, A., Soni, R., Hawaldar, I. T., Vyas, M., \& Yadav, V. (2020). The Testing of Efficient Market Hypotheses: A Study of Indian Pharmaceutical Industry. International Journal of Economics and Financial Issues, 10(3), 208216. https://doi.org/10.32479/ ijefi.9764

39. Kumar, K. R. N., Hawaldar, I. T. \& Mallikarjunappa, T. (2018). Windows of Opportunity and Seasoned Equity Offerings: An Empirical Study. Cogent Economics \& Finance, 6(1), 1-18. https://doi.or g/10.1080/23322039.2018.1528688

40. Lau, S. C., Quay, S. R., \& Ramsey, C. M. (1974). The Tokyo Stock Exchange and the Capital Asset Pricing Model. The Journal of Finance, 29(2), 507. https://doi. org/10.2307/2978820

41. Lintner, J. (1965). The Valuation of Risk Assets and the Selection of Risky Investments in Stock Portfolios and Capital Budgets. The Review of Economics and Statistics, 47(1), 13. https://doi. org/10.2307/1924119

42. Markowitz, H. (1952). Portfolio Selection. The Journal of Finance, 7(1), 77-91. https://doi. org/10.1111/j.1540-6261.1952 tb01525.x

43. Olakojo, S. A., \& Ajide, K. B. (2010). Testing the capital asset pricing model (CAPM): The case of the nigerian securities market. International Business Management, 4(4), 239-242. https://doi. org/10.3923/ibm.2010.239.242

44. Rahman, M., Baten, A., \& AshrafUl-Alam. (2006). An empirical testing of capital asset pricing model in Bangladesh. Journal of Applied Sciences, 6(3), 662667. https://doi.org/10.3923/ jas.2006.662.667

45. Sehgal, S., \& Balakrishnan, A. (2013). Robustness of FamaFrench Three-Factor Model: Further Evidence for Indian Stock Market. Vision: The Journal of Business Perspective, 17(2), 119-127. https://doi. org/10.1177/0972262912483526

46. Shaikh, S. A., Shaikh, R., \& Shaique, M. (2017). Applicability of CAPM: An Evidence from Pakistan Stock Exchange. Journal of Business Strategies, 11(2), 2134. Retrieved from http://www. greenwichjournals.com/index.php/ businessstudies/article/view/374 
47. Sharpe, W. F. (1964). Capital Asset Prices: a Theory of Market Equilibrium Under Conditions of Risk. The Journal of Finance, 19(3), 425-442. https://doi. org/10.1111/j.1540-6261.1964. tb02865.x

48. Sreenu, N. (2018). An Empirical Test of Capital Asset-pricing
Model and Three-factor Model of Fama in Indian Stock Exchange. Management and Labour Studies, 43(4), 294-307. https://doi. org/10.1177/0258042x18797770

49. Theriou, N. G., Aggelidis, V. P., Maditinos, D. I., \& Šević, Ž. (2010). Testing the relation between beta and returns in the Athens stock exchange. Managerial Finance, 36(12), 1043-1056. https://doi. org/10.1108/03074351011088441

50. Wong, K. A., \& Tan, M. L. (1991). An assessment of risk and return in the Singapore stock market. Applied Financial Economics, 1(1), 11-20. https://doi. org/10.1080/758520133 